\title{
ARTIKELEN
}

\section{Regelovertreding als voorspeller van incidenten in de chemische industrie ${ }^{*}$}

\author{
Ellen Wiering, Arjan Blokland, Marieke Kluin, Wim Huisman \& Marlijn Peeters
}

\begin{abstract}
Zowel in het oog springende rampen, als kleinere incidenten bij chemische bedrijven trekken een wissel op de leefomgeving. Brzo-regelgeving heeft als doel de gevolgen van chemische bedrijvigheid voor mens en milieu te beperken. Hieruit ontstaat de verwachting dat overtreding van deze regels voorspellend is voor het zich voordoen van incidenten. In de huidige studie worden de mogelijkheden onderzocht incidenten bij chemische bedrijven te voorspellen aan de hand van hun geschiedenis van regelovertreding, eerder gemelde incidenten en bedrijfskenmerken. Analyse van drie jaar aan inspectiegegevens en vijf jaar aan rapportage van incidenten toont aan dat de branche en het aantal eerder gemelde incidenten het plaatsvinden van een incident voorspellen. De bedrijfsgeschiedenis van regelovertreding voorspelt incidenten echter niet. Om het ontbreken van dit verband te kunnen duiden is nader onderzoek nodig.
\end{abstract}

\section{$1 \quad$ Inleiding}

De moderne samenleving wordt gekenmerkt door een sterke afhankelijkheid van complexe, geavanceerde technologiesystemen. Hoewel we er niet altijd bij stilstaan, spelen commerciële bedrijven en regulerende instanties een belangrijke rol bij het waarborgen van onze veiligheid. Berichten over verontreinigingen, ongevallen en rampen maken dit onaangenaam duidelijk en zijn dan ook vaak een bron van maatschappelijke onrust. In de afgelopen jaren trokken verschillende veiligheidsincidenten bij chemische bedrijven de aandacht. In sommige gevallen betrof het grootschalige branden en explosies (Volkskrant, 2011a; NRC, 2014; Volkskrant, 2011b), terwijl andere berichten betrekking hadden op meer sluimerende incidenten met schadelijke stoffen (Algemeen Dagblad, 2017; Eindhovens Dagblad, 2017; Volkskrant, 2017; Nu.nl, 2018; NRC, 2018). Dergelijke incidenten kunnen aanleiding zijn tot zorg voor werknemers, omwonenden en milieuorganisaties.

In Nederland gevestigde bedrijven waar hoeveelheden gevaarlijke stoffen aanwezig zijn boven een bepaalde drempelwaarde moeten daarom sinds 1982 voldoen aan de eisen neergelegd in het Besluit risico zware ongevallen (Brzo), de Nederlandse implementatie van de Europese Seveso-richtlijnen, bedoeld om de veilig-

\footnotetext{
* Het onderzoek waarop dit artikel is gebaseerd, is mede mogelijk gemaakt door het Programma
} Handhaving en Gedrag. 
heid te verbeteren van locaties met grote hoeveelheden gevaarlijke stoffen. Bedrijven die vallen onder de Brzo-regelgeving zijn onder meer verplicht tot het invoeren van een Preventiebeleid Zware Ongevallen (PBZO) en een veiligheidsbeheerssysteem (VBS). Het VBS bestaat uit zeven elementen die toezien op zaken als de organisatie en de werknemers, het identificeren van gevaren en risico's voor zware ongevallen en het handelingsplan voor noodsituaties. Regulering wordt beschouwd als belangrijke remedie tegen de ongewenste neveneffecten van de chemische industrie. In onderzoeksrapporten na afloop van grote incidenten wordt regelovertreding dan ook vaak aangewezen als contribuerende factor. Zo wees de Onderzoeksraad voor Veiligheid $(2012,2013)$ in zijn rapporten over Chemiepack en Odfjell op de vele regelovertredingen van beide bedrijven. Uit een studie binnen acht Europese landen, waaronder Nederland, blijkt bovendien dat het merendeel van de bedrijven, toezichthouders en andere stakeholders van mening is dat de Seveso-richtlijnen de veiligheid van Brzo-bedrijven hebben verhoogd (Salvi et al., 2008). Dit wekt de verwachting dat overtreding van deze regelgeving mogelijk voorspellend is voor het zich voordoen van incidenten.

Het verband tussen naleving van Seveso-richtlijnen en incidenten is echter nog nauwelijks onderwerp van wetenschappelijk empirisch onderzoek. Wel hebben verschillende studies de afgelopen decennia de relatie tussen veiligheidswetgeving en persoonlijke veiligheidsincidenten onderzocht. Zo werd het effect van invoering van veiligheidsregulering (Lewis-Beck \& Alford, 1980; Fishback, 1986; Curington, 1986; Arocena \& Nunez, 2009), inspecties (Smith, 1979; Boden, 1985) en handhaving (Gray \& Scholz, 1993; Gray \& Mendeloff, 2005) op arbeidsongevallen onderzocht in verschillende industriesectoren. De rol van regelovertreding komt in mindere mate aan de orde. Wel werd eerder de samenhang tussen zelfgerapporteerde overtreding van veiligheidsmaatregelen en arbeidsongevallen onder constructiewerkers (Aksorn \& Hadikusumo, 2008; Goldenhar, Williams \& Swanson, 2003), hoogspanningswerkers (Hayes, Perander, Smecko \& Trask, 1998) en werknemers van chemische bedrijven (Vinodkumar \& Bhasi, 2009) onderzocht. Deze studies laten een verband zien tussen overtreding van bepaalde veiligheidsmaatregelen en arbeidsongevallen. Onderzoek naar de voorspellende waarde van officiële, geregistreerde regelovertreding voor ongevallen en incidenten ontbreekt. In bestaande studies ligt de aandacht bovendien op het voorspellen van ongevallen met verzuim, een typische proxy voor persoonlijke veiligheidsongevallen. Onderzoek in dit kader naar loss of containment-incidenten, een indicator van procesveiligheid, is dun gezaaid.

In de huidige studie toetsen we op basis van longitudinale gegevens in welke mate het overtreden van de (Seveso-)veiligheidsregels in de periode 2012-2014 voorspellend is voor het zich voordoen van een incident bij een Brzo-bedrijf in de jaren 2015-2017. Specifiek richten we ons op de significante loss of containment-incidenten met (mogelijk) schadelijke gevolgen voor de omgeving, die Brzo-bedrijven wettelijk verplicht zijn te melden. Deze incidenten variëren van kleinere emissies van schadelijke stoffen tot grotere branden met gevaar voor explosie. Tijdens inspecties geconstateerde overtredingen van de veiligheidsregels worden, uitgesplitst naar type, meegenomen als voorspeller. Om de unieke bijdrage van regelovertreding aan de voorspelling van incidenten te kunnen vaststellen, wordt reke- 
ning gehouden met enkele bedrijfskenmerken. Ook de bedrijfsgeschiedenis van eerder gemelde incidenten wordt meegenomen als voorspeller van incidenten. Concreet beantwoorden we de volgende onderzoeksvragen:

1 Welk percentage van de Brzo-bedrijven in onze steekproef rapporteert een incident in de periode tussen januari 2015 en augustus 2017?

2 In hoeverre zijn het aantal en de aard van gerapporteerde incidenten (lagging indicatoren) tussen december 2012 en december 2014 voorspellend voor het zich voordoen van een incident in de periode tussen januari 2015 en augustus 2017?

3 In hoeverre zijn het aantal en de aard van geconstateerde regelovertredingen (leading indicatoren) tussen december 2012 en december 2014 voorspellend voor het zich voordoen van een incident in de periode tussen januari 2015 en augustus 2017

\section{Theoretisch kader}

\subsection{Procesveiligheid en persoonlijke veiligheid}

In het onderzoek naar veiligheid van organisaties wordt onderscheid gemaakt tussen procesveiligheid en persoonlijke veiligheid. Procesveiligheid refereert aan de veiligheid van operationele bedrijfsprocessen, in het geval van Brzo-bedrijven de productie, verwerking en/of opslag van gevaarlijke stoffen. Typische procesveiligheidsincidenten betreffen emissies van schadelijke stoffen en het vrijkomen van brandbare stoffen, met mogelijk explosies of branden tot gevolg (Hopkins, 2009). Persoonlijke veiligheidsincidenten staan daarentegen los van verstoringen van de veiligheid van primaire bedrijfsprocessen en betreffen veelal 'slips, trips, and falls ${ }^{1}$ In tegenstelling tot de consequenties van veel persoonlijke veiligheidsincidenten kunnen de gevolgen van procesgerelateerde incidenten desastreus zijn. De huidige studie richt zich op het voorspellen van incidenten die bedrijven in het kader van artikel 17.2 Wet milieubeheer verplicht zijn te melden aan het bevoegd gezag. Een ongewoon voorval in de zin van artikel 17.2 Wet milieubeheer omvat 'elke gebeurtenis in een inrichting, ongeacht de oorzaak van die gebeurtenis, die afwijkt van de normale bedrijfsactiviteiten. Dit begrip omvat derhalve zowel storingen in het productieproces en storingen in de voorzieningen van de inrichting als ongelukken en calamiteiten' (Afdeling Bestuursrechtspraak Raad van State 2 juni 2004, ECLI:NL:RVS:2004:AP0349). Verder is het voor de toepasselijkheid van het artikel vereist dat door het voorval nadelige gevolgen voor het milieu zijn ontstaan of dreigen te ontstaan. De wetgever heeft hiermee beoogd het bevoegd gezag in staat te stellen schade door incidenten te beperken en te voorkomen (Kenniscentrum InfoMil, 2018). Een voorbeeld van een ongewoon voorval is de uitstoot van gevaarlijke stoffen door een scheur in een installatie of een onbedoeld opengelaten afsluiter. Deze incidenten zijn zowel wat betreft aan-

1 Tegelijkertijd zijn de twee typen veiligheid niet volledig van elkaar te onderscheiden. Zo kunnen incidenten uit de categorie procesveiligheid ook leiden tot persoonlijke arbeidsongevallen. Vanwege de oorsprong en ontstaansroute van dit type incidenten worden deze toch als procesveiligheidsincident geclassificeerd (Swuste, Theunissen, Schmitz, Reniers \& Blokland, 2016). 


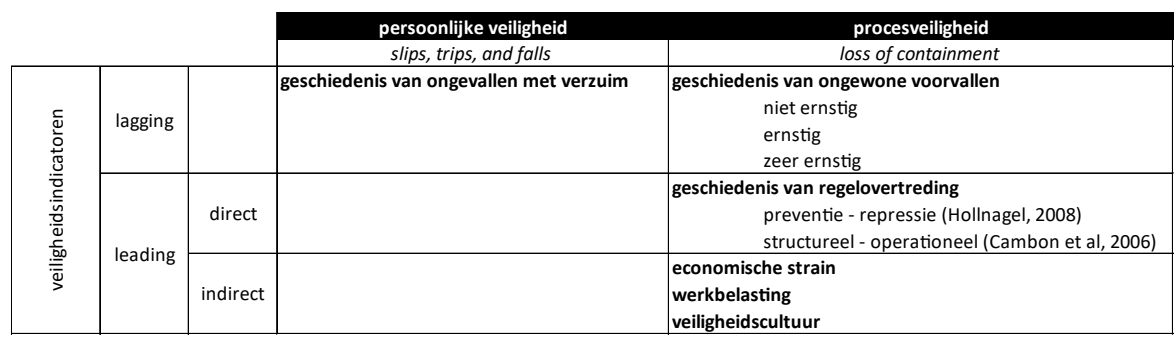

Figuur 1 Schematische weergave van de verschillende soorten veiligheid en de verschillende soorten veiligheidsindicatoren

loop als gevolg anders van aard dan de persoonlijke slips, trips and falls, en zullen over het algemeen neigen naar de categorie procesveiligheidsincidenten.

\subsection{Veiligheidsindicatoren}

In de Seveso-richtlijnen en onderliggende regelgeving heeft de wetgever gepoogd de belangrijkste elementen voor risicobeheersing op te nemen. De verschillende elementen van het veiligheidsbeheerssysteem (VBS) spelen hierbij een centrale rol. De mate van naleving van deze regelgeving zou dan ook een beeld kunnen schetsen van de veiligheidssituatie binnen een inrichting. Binnen de veiligheidsliteratuur wordt in dit kader gesproken over veiligheidsindicatoren. Veiligheidsindicatoren geven een indicatie van de veiligheidssituatie bij een bedrijf en bieden handvatten bij het monitoren en verbeteren van een systeem (Swuste, Theunissen, Schmitz, Reniers \& Blokland, 2016; Hale, 2009). Verschillende studies onderzochten de relatie tussen diverse veiligheidsindicatoren en arbeidsongevallen (zie bijvoorbeeld Brown \& Holmes, 1986; Hayes, Perander, Smecko \& Trask, 1998; Zohar, 2000; Vinodkumar \& Bhasi, 2009). Vaak wordt onderscheid gemaakt tussen leading en lagging indicatoren. Deze indicatoren kunnen in een kruistabel tegenover de beide typen veiligheid worden geplaatst, waardoor inzichtelijk wordt dat er voor zowel proces- als persoonlijke veiligheid leading en lagging indicatoren bestaan (Hopkins, 2009) (zie figuur 1).

\subsection{Leading veiligheidsindicatoren}

Leading veiligheidsindicatoren worden gedefinieerd als omstandigheden of gebeurtenissen die voorafgaan aan ongewenste gebeurtenissen (Grabowski, Ayyalasomayajula, Merrick, Harrald \& Roberts, 2007). Dit type indicator wordt gemeten nog voordat het risico op een ongewenste gebeurtenis zich verwerkelijkt en heeft derhalve voorspellende waarde voor gebeurtenissen als ongevallen, near misses en andere veiligheidsincidenten. In de literatuur wordt onderscheid gemaakt tussen verschillende categorieën leading indicatoren, welke in meer of mindere mate herleidbaar zijn naar Brzo-regelgeving.

Een eerste onderscheid binnen de leading indicatoren is dat tussen preventieve en repressieve maatregelen. Preventieve maatregelen kunnen worden gezien als maatregelen die zijn gericht op het terugdringen van de kans op een ongewenste 
gebeurtenis. Aangezien het voorkomen van ieder incident in de praktijk vaak onmogelijk is, zijn ook repressieve maatregelen van belang (Hollnagel, 2008). Dit type maatregel is gericht op het voorkomen of indammen van de gevolgen van een ongewenste gebeurtenis. Bij het voorspellen van het zich voordoen van een incident zal daarom met name de structurele preventie van belang zijn. Wanneer wordt gefocust op de ernst van een incident, zullen ook repressieve maatregelen een rol gaan spelen. Immers, in het geval dat de juiste repressieve maatregelen worden genomen, kan de ernst van een incident worden beperkt. De door inspectiediensten geïnspecteerde onderwerpen zijn in sommige gevallen aan te merken als preventief dan wel repressief. Zo is VBS element V volledig gericht op de planning van noodsituaties en dus repressief van aard. Tegelijkertijd lopen de twee typen op andere onderdelen meer door elkaar heen. Zo heeft VBS element I betrekking op de organisatie en werknemers. Werknemers kunnen in het kader daarvan bijvoorbeeld getraind worden op het volgen van veiligheidsprocedures tijdens het uitvoeren van operationele taken, waardoor incidenten kunnen worden voorkomen, maar ook op het repressief handelen bij emissies of andere incidenten. Maatregelen binnen dit kader zijn dus zowel preventief als repressief van aard.

Daarnaast maken Cambon, Guarnieri en Groeneweg (2006) in het kader van veiligheidsmanagementsystemen het onderscheid tussen structurele en operationele veiligheid. De structurele component wordt hierbij omschreven als het geformaliseerde streven naar veiligheid. In de Seveso-richtlijnen kan deze component worden teruggevonden in het vereiste dat veiligheidsmanagementprocessen moeten worden neergelegd in procedures, richtlijnen en standaarden. De veiligheid 'op papier' is echter niet vanzelfsprekend een juiste weergave van de werkelijke staat van de veiligheid binnen een bedrijf. De operationele component is daarom een belangrijke aanvulling op de structurele component en geeft aan hoe de zaken daadwerkelijk in zijn werk gaan. Tijdens Brzo-inspecties wordt ten eerste gekeken naar de mate waarin bedrijven maatregelen hebben beschreven en in hoeverre deze adequaat zijn (LAT Brzo, 2008). Dit kan worden aangemerkt als een indicatie van de structurele veiligheid. Daarnaast wordt gecontroleerd of er binnen bedrijven daadwerkelijk zo wordt gewerkt als beschreven, wat kan worden gezien als een weergave van de operationele veiligheid. Het voorgaande kan worden teruggevonden in de drie beoordelingsgrondslagen 'gedocumenteerd' en 'geschikt' (structureel) en 'geïmplementeerd' (operationeel), waarop inspecteurs hun bevindingen beoordelen. De drie grondslagen worden ieder afzonderlijk beoordeeld als slecht, matig, redelijk of goed. De uitkomst van de beoordelingen leidt tot het al dan niet kenmerken van de bevindingen als overtreding en bepaalt de hoogte van de eventuele bijbehorende boete (Beleidsregel boeteoplegging BRZO 1999 Bijlage II; Beleidsregel handhaving- en sanctioneringkader Besluit risico's zware ongevallen 2015 arbeidsomstandighedenwetgeving Bijlage II).

\subsection{Lagging indicatoren}

Naast leading indicatoren kunnen ook lagging indicatoren relevant zijn voor het voorspellen van incidenten. Daar waar leading indicatoren voorafgaand aan ongewenste gebeurtenissen worden gemeten, zijn lagging indicatoren outputme- 
tingen. Deze worden dus na afloop van ongewenste gebeurtenissen gedaan. Een voorbeeld van een lagging indicator voor persoonlijke veiligheid is het aantal eerdere arbeidsongevallen met letsel of verzuim tot gevolg. Voor procesveiligheid kan het aantal incidenten waarbij gevaarlijke stoffen vrijkwamen bijvoorbeeld dienen als lagging indicator. Hoewel lagging indicatoren in de eerste plaats een weerspiegeling zijn van het verleden, kunnen ze in sommige gevallen eveneens de mate reflecteren waarin een bedrijf de veiligheid goed beheerst, en dus ook een voorspellende waarde hebben. Hierbij is het niveau van de incidenten waarop wordt gefocust van belang (Hopkins, 2009). Het feit dat zich in de afgelopen jaren bij een bedrijf geen grootschalige ramp heeft voorgedaan geeft, vanwege de zeldzaamheid van het zich voordoen van rampen, geen enkele garantie van een veilige situatie bij dat bedrijf. De bedrijfsgeschiedenis met betrekking tot minder ernstige incidenten is in dit opzicht vele malen informatiever. De geschiedenis van incidenten kan dus een voorspellende waarde hebben voor toekomstige incidenten, mits deze incidenten zich frequent genoeg voordoen.

\subsection{Veiligheidsmodellen}

De selectie van indicatoren voor de veiligheidssituatie, en dus mogelijke voorspellers van incidenten, is (impliciet) gebaseerd op veiligheidsmodellen en -theorieën (Lundberg, Rollenhagen \& Hollnagel, 2008; Swuste, Theunissen, Schmitz, Reniers \& Blokland, 2016). Om een beeld te verkrijgen van de manier waarop gebeurtenissen, handelingen en omstandigheden kunnen uitmonden in een ongeval of incident, wordt een beknopt overzicht geschetst van bestaande modellen. Binnen de veelheid aan voorgestelde veiligheidsmodellen, -theorieën en -analogieën kan grofweg onderscheid worden gemaakt tussen sequentiële, epidemiologische en systeemdynamische modellen. Sequentiële ongevalsmodellen zien ongevallen als het gevolg van een reeks gebeurtenissen die plaatsvinden in een bepaalde chronologische volgorde (Hollnagel, 2004). De dominotheorie van Heinrich (1959) is een van de vroegste modellen uit deze categorie en gebruikt het vallen van dominostenen als metafoor voor een lineaire opeenvolging van gebeurtenissen. Deze reeks van gebeurtenissen vindt zijn oorsprong in een eerste factor, de grondoorzaak, en resulteert uiteindelijk in een ongeval. De traditionele sequentiële modellen gelden als belangrijke eerste stappen in de ontwikkeling van de veiligheidstheorie, maar worden als ontoereikend gezien als het gaat om het verklaren van ongevallen in moderne sociaaltechnologische systemen, waar verschillende factoren op complexe wijze samenkomen en resulteren in ongevallen.

De epidemiologische benadering kwam op in de jaren tachtig en voorzag deels in de behoefte aan een beter begrip van ongevallen. Epidemiologische modellen beschouwen ongevallen als de uitkomst van een combinatie van waarneembare en niet-waarneembare factoren. Bekende epidemiologische modellen zijn het in de praktijk veel gebruikte vlinderdasmodel (zie bijvoorbeeld Brzoplus, 2014), de incubatietheorie (Turner \& Pidgeon, 1997) en het Zwitserse kaasmodel (Reason, 1990). Het laatstgenoemde model illustreert hoe de combinatie van latente, structurele gebreken (resident pathogens) en actieve fouten, zoals gevaarlijke handelingen, resulteert in ongevallen. Epidemiologische modellen betekenen ten opzichte van sequentiële modellen een verbetering in de zin dat deze verder kij- 


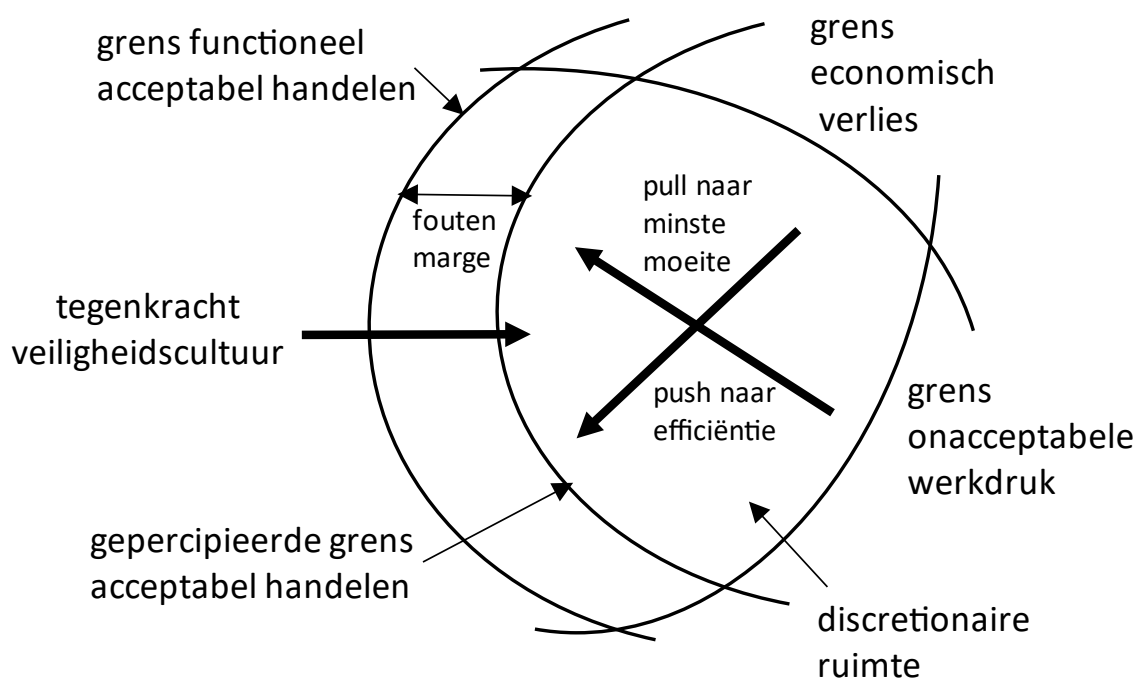

Figuur 2 Drift to danger-model (Rasmussen, 1997)

ken dan één enkele en proximale oorzaak. Desondanks kreeg ook de epidemiologische stroming kritiek te verduren, omdat de modellen nog altijd lineair en statisch van aard zijn.

De vraag naar een dynamische benadering, waarin niet alleen lineaire maar ook complexe interacties van verschillende factoren centraal staan, leidde tot de opkomst van de systeemdynamische benadering van ongevalsverklaring. In deze modellen wordt de onderlinge verwevenheid en afhankelijkheid van de menselijke, organisatorische en technische elementen bezien en staat de prestatie van het systeem als geheel centraal (Qureshi, 2007). Het systeem wordt hierbij niet gezien als statisch, maar als dynamisch proces, dat zichzelf continu aanpast om zijn doelen te behalen en reageert op interne en externe veranderingen. Een bekend voorbeeld van een systeemdynamisch model is de normal accident-theorie, waarmee Perrow (1984) zware ongevallen verklaart. Het drift to danger-model van Rasmussen (1997), weergegeven in figuur 2, valt eveneens binnen deze categorie. Het drift to danger-model beschrijft hoe bedrijven onder economische prestatiedruk hun streven naar winst en efficiëntie steeds verder opvoeren en richting de grens van veilig werken opschuiven. Deze grens wordt bewaakt door regelgeving, richtlijnen, procedures en andere veiligheidsmaatregelen. In eerste instantie komt het bedrijf terecht in een staat waarin betere prestaties worden geleverd, doordat de nadelen van regeldruk als verminderde efficiëntie en hogere werkdruk afnemen. Wanneer echter nog verder wordt opgeschoven, beginnen zich regelovertredingen en andere onregelmatigheden voor te doen. Wordt de uiterste grens van veilig werken overschreden, dan leidt dit tot ongevallen. 
Het drift to danger-model toont gelijkenissen met de strain-theorie van socioloog Merton (1938) en de recentere uitwerking hiervan door Agnew (1992). Deze theorie stelt dat discrepantie tussen culturele doelen en beschikbare institutionele middelen om deze te bereiken, leidt tot spanning (strain). Indien men vast blijft houden aan de culturele doelen, kan dit, wanneer legitieme middelen als ontoereikend worden ervaren, leiden tot een neiging naar illegitieme middelen en deviant gedrag. Strain-theorie werd in eerste instantie gebruikt om criminaliteit in de onderste laag van de Amerikaanse samenleving te verklaren, maar werd later eveneens toegepast op organisatiecriminaliteit (zie bijvoorbeeld Braithwaite, 1992; Waring, Weisburd \& Chayet, 1995; Simpson \& Koper, 1997; Passas, 1990; Jenkins \& Braithwaite, 1993; Langton \& Piquero, 2007; Agnew, Piquero \& Cullen, 2009). Aangezien voor bedrijven financieel gewin geldt als een van de meest prominente doelen, zullen bedrijven die financieel onder druk staan volgens de strain-theorie eerder geneigd zijn illegale werkwijzen aan te wenden. Verschillende studies vonden een verband tussen slechte financiële bedrijfsprestaties en regelovertredingen (Staw \& Szwajkowski, 1975; Clinard \& Yeager, 1980; Filer \& Golbe, 2003). Ook financieel gezonde bedrijven kunnen echter regelovertredend gedrag vertonen als gevolg van strain (Clinard \& Yeager, 1980). Interne, subjectieve afwegingen binnen een bedrijf kunnen leiden tot de beleving van een problematische situatie, zelfs wanneer objectieve deprivatie niet aan de orde is (Passas, 1990).

\section{Data en methode}

\subsection{Brzo-bedrijven}

Onder Brzo-bedrijven vallen ongeveer vierhonderd Nederlandse bedrijven die vanwege de aanwezigheid van grote hoeveelheden gevaarlijke stoffen worden aangemerkt als hoog-risicobedrijf. Brzo-bedrijven variëren van kleinschalige bedrijven voor opslag en distributie van gevaarlijke stoffen, tot complexe (petro)chemische fabrieken. De veiligheidseisen waaraan deze bedrijven moeten voldoen, zijn neergelegd in het Besluit risico's zware ongevallen 2015, de Nederlandse uitwerking van de Europese Seveso III-richtlijn. De naleving van deze veiligheidseisen wordt periodiek gecontroleerd door middel van on-site inspecties. De huidige analyses hebben, vanwege de beschikbaarheid van incidentregistraties, enkel betrekking op Brzo-bedrijven gevestigd in de (veiligheids)regio Rijnmond.

\subsection{Incidenten}

Ongewone voorvallen als bedoeld in artikel 17.2 van de Wet milieubeheer variëren in ernst van grootschalige rampen met aanzienlijke schade aan het milieu tot kleine incidenten zonder significante gevolgen. De regio Rijnmond maakt gebruik van het Centraal Incidenten Nummer (CIN). Meldingen die via dit nummer zijn gedaan, komen direct binnen bij operationele diensten die naar aanleiding hiervan mogelijk in actie moeten komen (DCMR, 2017). Een deel van deze gemelde incidenten wordt sinds december 2012 gepubliceerd op de website 
www.rijnmondveilig.nl/cin-meldingen. Dit betreft de incidenten die (mogelijk) leiden tot gevaar binnen en/of buiten het bedrijfsterrein, tot overlast voor de omgeving of tot nadelige effecten op het milieu. Ook branden en explosies worden derhalve op de website gepubliceerd. Deze meldingen staan in dit hoofdstuk centraal en worden aangeduid als incidenten. Deze incidenten betreffen niet enkel incidenten waarbij gevaarlijke stoffen in de zin van het Brzo 2015 zijn betrokken. Het kan bijvoorbeeld ook gaan om een brand bij een Brzo-bedrijf waarbij geen gevaarlijke stof is betrokken, maar welke desondanks in potentie een nadelig effect op de omgeving heeft.

Gegevens over alle incidenten die door Brzo-bedrijven in de regio Rijnmond zijn gemeld tussen december 2012 en augustus 2017 zijn ingevoerd in SPSS. Tabel 1 toont de tien verschillende categorieën waarin gemelde incidenten worden ingedeeld. Voor de analyses wordt onderscheid gemaakt tussen incidenten zonder gevaar en incidenten met gevaar. De incidenten zonder gevaar bestaan uit meldingen uit de categorieën 2, 7, 8, 9 en 10 en de incidenten met gevaar betreffen de categorieën $1,3,4,5$ en 6 .

Aangezien het gaat om door bedrijven zelf gemelde incidenten, bestaat de kans op vertekening. Het is immers denkbaar dat veilige bedrijven beter aan hun meldingsplicht voldoen dan onveilige bedrijven en dat veilige bedrijven daarom juist meer in plaats van minder incidenten rapporteren dan onveilige bedrijven. De kans op vertekening door verschillen in bereidheid tot zelfrapportage is vermoedelijk kleiner bij incidenten uit categorie 1. Deze incidenten betreffen branden waarbij het bedrijf assistentie van de brandweer vraagt. In deze gevallen is het bedrijf zelf niet in staat de brand te beheersen en daarom gedwongen de brandweer in te schakelen en het incident derhalve te melden. Om te controleren voor mogelijke vertekening als gevolg van de zelfrapportage door bedrijven worden niet alleen incidenten met gevaar, maar ook enkel de incidenten uit categorie 1 , de grotere branden, voorspeld. Als lagging indicatoren worden daarbij het aantal eerder gemelde incidenten met gevaar en eerder gemelde incidenten zonder gevaar toegevoegd aan het voorspellingsmodel van incidenten met gevaar. Voor het voorspellen van grotere branden wordt het aantal eerder gemelde grotere branden en andersoortige incidenten toegevoegd als voorspellers.

\subsection{Gemeenschappelijke Inspectie Ruimte (GIR)}

De onderzoeksdata met betrekking tot regelovertreding van Brzo-bedrijven zijn verkregen uit de Gemeenschappelijke Inspectie Ruimte (GIR). De drie samenwerkende inspectiediensten die toezichthouden op Brzo-bedrijven (Wabo bevoegd gezag, Inspectie SZW en Veiligheidsregio) gebruiken deze online database bij de voorbereiding, uitvoering en afronding van gezamenlijke Brzo-inspecties. In de GIR staat vermeld welke onderwerpen voor een inspectie zijn gepland en welke daadwerkelijk zijn geïnspecteerd. Ook registreren inspecteurs welke overtredingen tijdens de inspectie eventueel zijn geconstateerd en welke handhavingsacties hierop zijn ondernomen. De GIR-database is niet primair ontwikkeld voor analysedoeleinden en vertoont hierdoor de daarmee gepaard gaande beperkingen (Bureau Bartels, 2012). Grondige opschoning en bewerking is derhalve nodig om 
Tabel 1 Categorieën van gemelde incidenten

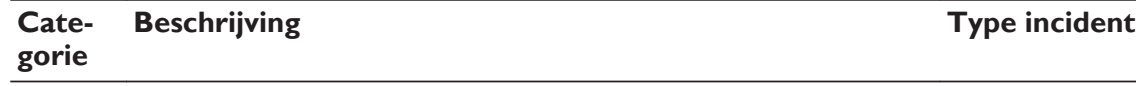

Brand

I Brand/Broei/Explosie met verzoek om assistentie brandweer

grotere brand

2 Brand/Broei/Explosie zonder verzoek om assistentie brandweer zonder gevaar Gevaar buiten de inrichting

3 Gevaar: verspreiding van stoffen door de lucht

met gevaar

4 Gevaar: verspreiding van stoffen op of in het oppervlaktewater met gevaar

5 Gevaar: verspreiding van stoffen over het land met gevaar

Gevaar binnen de inrichting

6 Gevaar: binnen de inrichting of overige (potentieel) gevaarlijke met gevaar gevolgen met assistentie brandweer

Geen gevaar

7 Geen gevaar: verspreiding van stoffen door de lucht

zonder gevaar

8 Geen gevaar: verspreiding van stoffen op of in het oppervlaktezonder gevaar water

9 Geen gevaar: verspreiding van stoffen over het land zonder gevaar

10 Geen gevaar: overige overlastgevende situatie (bijvoorbeeld stroomstoring)

zonder gevaar

verdere analyse mogelijk te maken (zie Kluin, Blokland, Huisman, Peeters, Wiering \& Jaspers (2018) voor een uitgebreide beschrijving van de gebruikte dataset). Hoewel de GIR data van alle Nederlandse Brzo-bedrijven bevat, worden in de huidige studie alleen gegevens van Brzo-bedrijven geanalyseerd die zijn gevestigd in de regio Rijnmond. Deze selectie wordt gemaakt, omdat op dit moment alleen data met betrekking tot incidenten van bedrijven uit de (Veiligheids)regio Rijnmond voorhanden zijn. In totaal deden 69 Brzo-bedrijven gevestigd in de regio Rijnmond ten minste één melding van een incident in de periode 2012-2017. Van vier van deze bedrijven bleken echter geen inspectiegegevens bekend tussen 2012-2014, omdat zij in die periode nog niet onder de Seveso-richtlijn vielen. De huidige analyses hebben derhalve betrekking op 65 Brzo-bedrijven, gevestigd in de regio Rijnmond die in de periode 2012-2014 ten minste een keer geïnspecteerd zijn en die tussen 2012-2017 ten minste één melding deden van een incident.

\subsection{Regelovertreding}

De 65 Brzo-bedrijven in de huidige steekproef werden tussen 2012 en 2014 in totaal 273 keer geïnspecteerd; gemiddeld 4,2 keer per bedrijf. Op basis van de in de GIR aanwezige inspectieverslagen werden 140 mogelijke overtredingstypen onderscheiden. Deze werden voor de huidige analyses teruggebracht tot 12 categorieën, waarvan 8 gebaseerd op de elementen van het veiligheidsbeheerssysteem. ${ }^{2}$ De mate van regelovertreding is in eerste instantie bepaald aan de hand 
van het aantal tijdens deze inspecties geregistreerde overtredingen, waarbij rekening is gehouden met het aantal keren dat een bedrijf in die periode werd geïnspecteerd. Voor elke overtreding wordt sinds 2012 in de GIR ook de ernst weergegeven. Hierbij wordt onderscheid gemaakt tussen overtredingen die leiden tot gering gevaar, verhoogd gevaar en onmiddellijk gevaar voor personeel en omgeving. In de voorspellingsmodellen is nagegaan of de voorspellende waarde van de overtredingsgeschiedenis afhangt van de ernst van die betreffende overtredingen. Daarnaast is per bedrijf de verscheidenheid van de regelovertreding als variabele toegevoegd. Hierdoor is naast het gemiddelde aantal overtredingen per inspectie ook het gemiddelde aantal verschillende overtreden inspectieonderwerpen meegenomen in de analyses.

Regelovertredingen worden bovendien ingedeeld in de eerder besproken categorieën leading veiligheidsindicatoren. Overtredingen op het gebied van ageing, onderhoud, VBS-element III (controle op de exploitatie) en VBS-element VI (toezicht op de prestaties) zijn gecodeerd als leading veiligheidsindicatoren in de categorie preventie. Onder overtredingen van regels die betrekking hebben op het indammen van de gevolgen van eenmaal opgetreden veiligheidsincidenten, de repressieve leading veiligheidsindicatoren, worden overtredingen op VBS-element V (planning van noodsituaties), brandbeveiliging, scenario's, noodplan, noodorganisatie, rampenbestrijding en bedrijfsbrandweer gerekend. Overtredingen die niet vallen onder de categorieën preventief of repressief zijn gecategoriseerd als 'overig'. Verder wordt onderscheid gemaakt tussen structurele en operationele leading veiligheidsindicatoren. Het structurele aspect wordt in de huidige studie geoperationaliseerd als de gemiddelde score op de beoordelingsgronden 'gedocumenteerd' en 'geschikt' en het operationele aspect door de gemiddelde score op de beoordelingsgrond 'geïmplementeerd'. Per indeling in type veiligheidsindicatoren is een aparte analyse uitgevoerd.

\subsection{Bedrijfskenmerken}

In de verschillende voorspellingsmodellen wordt gecontroleerd voor bedrijfssector door bedrijven in te delen in vier categorieën op basis van het door de EU in het leven geroepen Major Accident Reporting System (MARS). Ruim 29\% van de bedrijven in de huidige steekproef valt in de MARS-categorie bulkchemie. Bijna $48 \%$ valt in de MARS-categorie handel en distributie. Nog eens $18 \%$ valt onder één van de overige MARS-categorieën, zoals olie, rubber, plastic of fijnchemie. De resterende $5 \%$ valt buiten de bestaande MARS-categorieën en is gecodeerd als 'overig'. Vijftig bedrijven konden bovendien worden aangemerkt als 'dominobedrijf. Een domino-bedrijf verkeert in de directe nabijheid van een andere hogeof lagedrempelinrichting (art. 6 lid 1 onder h Brzo 2015), waardoor een ongeval of ongewenste gebeurtenis grotere en ernstigere gevolgen kan hebben. Een aanwijzing als domino-bedrijf brengt extra verplichtingen voor het betreffende bedrijf met zich mee. Aangezien het aantal geregistreerde bedrijfskenmerken in de GIR beperkt is, zijn deze aangevuld op basis van gegevens aanwezig in de database van Company.Info, die op zijn beurt weer gevoed wordt door gegevens van de Kamer van Koophandel. Niet alle in de steekproef opgenomen bedrijven konden worden teruggevonden in de Company.Info database, bijvoorbeeld omdat er sprake was 
van een geconsolideerde jaarrekening en er hierdoor geen gegevens beschikbaar waren over de afzonderlijke bedrijfslocatie. Momenteel zijn daarom alleen gegevens met betrekking tot de bedrijfsomvang meegenomen om te kunnen controleren voor het mogelijke verband tussen de grootte van een bedrijf en de kans op een ongeval.

\subsection{Overlevingsduuranalyse}

De gemelde incidenten worden voorspeld aan de hand van overlevingsduuranalyses. Met overlevingsduuranalyse kunnen de longitudinale gegevens worden geanalyseerd, rekening houdend met het feit dat niet elk bedrijf voor dezelfde periode wordt geobserveerd en/of een incident voor het einde van de observatieperiode heeft gemeld. Eerst wordt een (non-parametrische) Kaplan Meier-overlevingsduuranalyse gebruikt om gedurende elke maand na 1 januari 2015 de kans te schatten dat een melding van een grotere brand of een incident met gevaar wordt gedaan door een van de bedrijven die (a) tot op dat moment nog geen melding hebben gedaan van een grotere brand of een incident met gevaar en (b) nog niet uit de studie zijn gevallen (bijv. omdat een bedrijf inmiddels opgehouden is te bestaan of niet meer valt onder de Brzo-regelgeving). De resultaten van een Kaplan Meier-analyse worden weergegeven in een zogenoemde survival curve, de cumulatieve proportie van het aantal bedrijven dat 'overleeft', dat wil zeggen dat het bedrijf op dat moment nog geen melding heeft gedaan van een incident met gevaar of een grotere brand. Vervolgens gebruiken we een Cox-regressiemodel om de effecten van bedrijfskenmerken, bedrijfsgeschiedenis van overtredingen en bedrijfsgeschiedenis van eerdere incidentmeldingen op de 'overleving' te schatten. Het Cox-regressiemodel geeft deze effectschattingen weer in hazard ratio's, waarbij hazard ratio's kleiner dan 1 aangeven dat de betreffende variabele het risico op het melden van een grotere brand of incident met gevaar verkleint, terwijl hazard ratio's groter dan 1 aangeven dat de betreffende variabele dit risico vergroot. Een hazard ratio van 1 geeft ten slotte aan dat er geen effect van de variabele is.

\section{Resultaten}

Van de 65 bedrijven in de steekproef 'overleeft' 38,5\% de 32 maanden na 1 januari 2015 zonder een incident met gevaar te melden (zie figuur 3 linkerpaneel). Dat wil dus zeggen dat 40 van de 65 bedrijven ten minste één incident met gevaar meldt binnen deze 32 maanden. De gemiddelde duur tot deze eerste melding is 18,5 maanden (95\% BI 15,616-21,360). Wanneer we onze analyses beperken tot meldingen van categorie 1 , oftewel branden waarbij assistentie van de brandweer gevraagd is, blijkt dat $55,4 \%$ van de bedrijven vrij blijft van dergelijke branden in de periode 2015-2017 (zie figuur 3 rechterpaneel). De 29 bedrijven die een grotere brand melden, doen dit na gemiddeld 22,3 maanden (95\% BI 19,624-24,980). Beide curven vertonen bovendien een geleidelijk verloop. Er lijkt derhalve geen tweedeling te bestaan tussen een groep bedrijven die 
Tabel 2 Beschrijvende statistieken voor de steekproef

\begin{tabular}{|c|c|c|c|}
\hline & range & $\%$ / gem. & STD \\
\hline \multicolumn{4}{|l|}{ MARS-categorie } \\
\hline bulkchemie & $0-1$ & 29,23 & \\
\hline olie, rubber, plastic en fijnchemie & $0-1$ & 18,46 & \\
\hline handel en distributie & $0-1$ & 47,69 & \\
\hline overig MARS & $0-1$ & 4,62 & \\
\hline \multicolumn{4}{|l|}{ Domino } \\
\hline ja & $0-1$ & 76,92 & \\
\hline \multicolumn{4}{|l|}{ Bedrijfsgrootte* } \\
\hline micro & $0-1$ & 23,68 & \\
\hline klein & $0-1$ & 23,68 & \\
\hline middelgroot & $0-1$ & 18,42 & \\
\hline groot & $0-1$ & 34,21 & \\
\hline \multicolumn{4}{|l|}{ Inspectiegeschiedenis $2012-2014$} \\
\hline aantal inspecties per bedrijf & $\mathrm{I}-7$ & 4,20 & 1,05 \\
\hline totaal aantal inspectieonderwerpen & $3-50$ & 31,23 & 9,36 \\
\hline aantal verschillende inspectieonderwerpen & $3-13$ & 9,55 & $\mathrm{I}, 83$ \\
\hline \multicolumn{4}{|l|}{ Overtredingsgeschiedenis $2012-2014$} \\
\hline aantal overtredingen & $0-47$ & 13,85 & 11,15 \\
\hline aantal verschillende overtredingen & $0-9$ & 4,48 & 2,74 \\
\hline aantal overtredingen preventief & $0-21$ & 2,66 & 4,01 \\
\hline aantal overtredingen repressief & $0-5$ & $\mathrm{I}, 3 \mathrm{I}$ & $\mathrm{I}, 38$ \\
\hline aantal overtredingen overig & $0-34$ & 9,82 & 7,7I \\
\hline gemiddelde score structureel** & $1,0-3,0$ & $\mathrm{I}, 87$ & 0,43 \\
\hline gemiddelde score operationeel** & $\mathrm{I}, 2-3, \mathrm{I}$ & 1,97 & 0,43 \\
\hline \multicolumn{4}{|l|}{ Geschiedenis incidenten 2012-2014 } \\
\hline aantal incidenten zonder gevaar & $0-44$ & 4,40 & 8,21 \\
\hline aantal incidenten met gevaar & $0-8$ & 0,83 & I,7। \\
\hline aantal grotere branden & $0-4$ & 0,34 & 0,87 \\
\hline
\end{tabular}

* Informatie over bedrijfsgrootte is slechts beschikbaar voor $58,5 \%(n=38)$ van de betreffende bedrijven.

** Informatie over structurele en operationele veiligheidsindicatoren is beschikbaar voor $96,9 \%$ $(n=63)$ van de betreffende bedrijven.

snel een grotere brand melden en een groep bedrijven die dit niet of pas veel later doen.

Om de voorspellende waarde van de geschiedenis van regelovertreding, eerdere incidentmeldingen en enkele bedrijfskenmerken voor het zich (opnieuw) voordoen van een incident met gevaar of een grotere brand te bepalen, zijn verschillende Cox-regressies geschat. Model A in tabel 3 geeft de hazard ratio's weer voor 


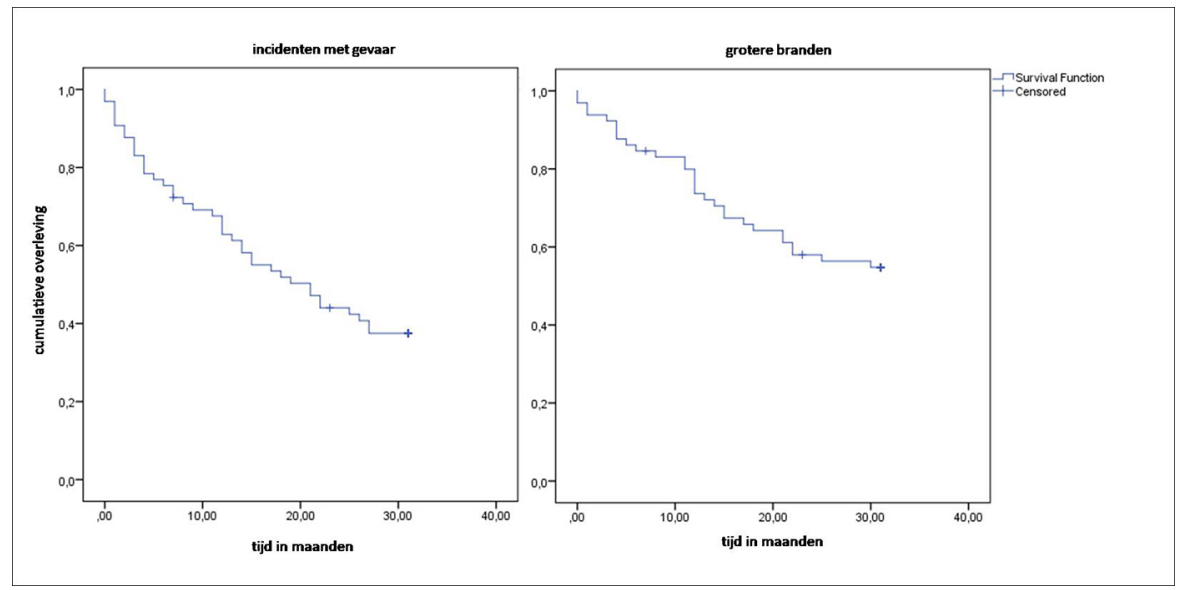

\section{Figuur 3 Overlevingscurve voor incidenten met gevaar (links) en grotere branden (rechts)}

verschillende bedrijfskenmerken. De kans op het melden van een incident met gevaar in de 32 maanden na 1 januari 2015 is voor bedrijven in de bulkchemie ruim twee keer groter dan voor bedrijven die vallen onder de MARS-categorie handel en distributie. Voor bedrijven in de MARS-categorie olie, rubber, plastic en fijnchemie is deze kans ruim drie keer groter. In model B in tabel 3 is ook de bedrijfsgeschiedenis van regelovertreding meegenomen, in dit model geoperationaliseerd als het gemiddeld aantal geconstateerde overtredingen per inspectieonderwerp in de periode 2012-2014. Hoewel de geschatte hazard ratio groter is dan 1, ligt de waarde 1 wel binnen het betrouwbaarheidsinterval. Dit betekent dat niet kan worden uitgesloten dat de geschatte hazard ratio berust op toeval. Op basis van deze resultaten concluderen we dat het aantal overtredingen in de periode 2012-2014 geen voorspellende waarde heeft voor het doen van een melding van een incident met gevaar tussen 2015-2017.

De overtredingsgeschiedenis in model B is gebaseerd op het aantal eerdere overtredingen. Ook andere aspecten van de overtredingsgeschiedenis kunnen echter van belang zijn. Op basis van de hierboven besproken indelingen in leading veiligheidsindicatoren, zijn verschillende Cox-regressies geschat waarin de overtredingsgeschiedenis van bedrijven steeds op een andere manier werd geoperationaliseerd. Figuur 4 geeft de belangrijkste resultaten van deze modellen op een visuele manier weer. In figuur 4 staat de zwarte stip voor de geschatte parameterwaarde (hazard ratio). De horizontale foutenbalken geven het $95 \%$ betrouwbaarheidsinterval aan. Alleen parameters waarvan het totale betrouwbaarheidsinterval naast de waarde 1 ligt, dragen significant bij aan het risico op het melden van een incident met gevaar of grotere brand. Figuur 4A laat zien dat overtredingsgeschiedenis, ongeacht de wijze van operationaliseren, geen voorspellende waarde heeft voor het melden van een incident met gevaar. Uit figuur $4 \mathrm{~B}$ blijkt dat dit eveneens geldt voor het melden van grotere branden. 
De lagging veiligheidsindicatoren - het aantal tussen 2012-2014 gemelde incidenten met gevaar en zonder gevaar en het aantal tussen 2012-2014 gemelde grotere branden en andersoortige incidenten - blijken wel significante voorspellers van het melden van een incident met gevaar en grotere branden tijdens de 36 maanden na 1 januari 2015. De parameterschatting van incidenten zonder gevaar is klein (maar wel significant). Met elke extra melding van een incident met gevaar tussen 2012-2014 stijgt het risico op een nieuw incident met gevaar echter met $33 \%$ (figuur $4 \mathrm{~A}$ ). Elke extra melding van een grotere brand doet het risico op een nieuwe melding van een grotere brand stijgen met $139 \%$ (figuur $4 \mathrm{~B}$ ).

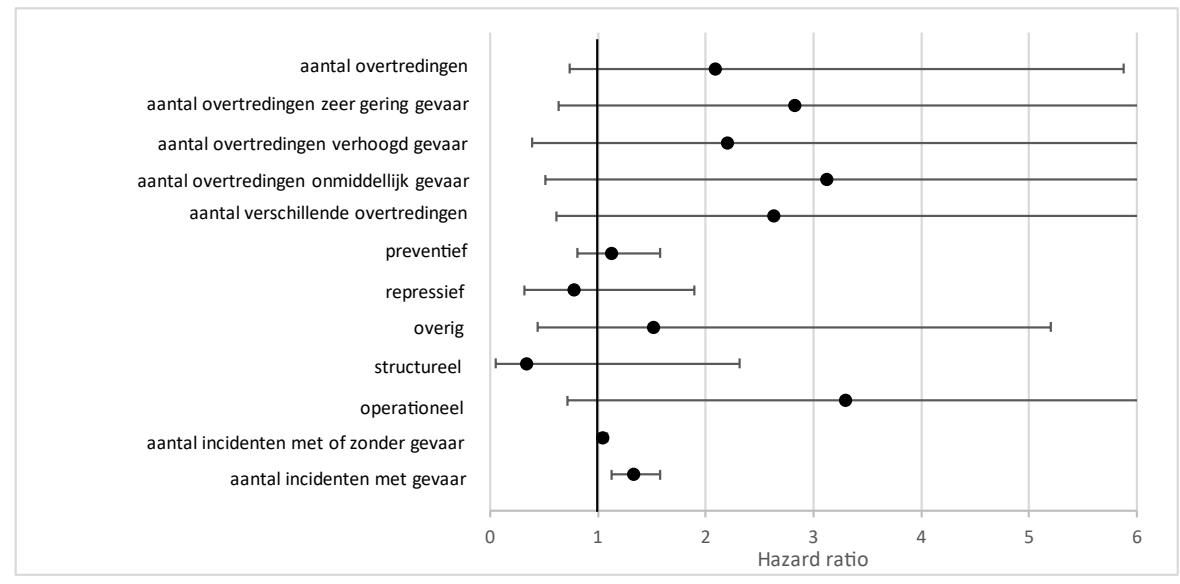

Figuur $4 A$ Incidenten met gevaar

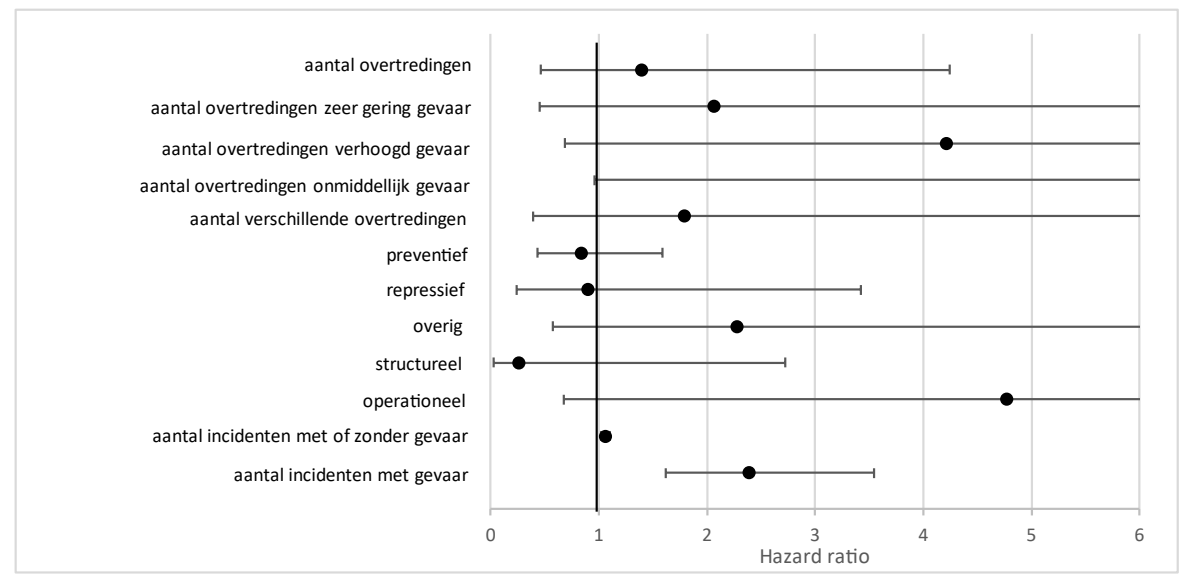

\section{Figuur $4 B$ Grotere branden}

Figuur $4 A$ en $4 B$ Hazard ratio's voor verschillende operationalisaties bedrijfsgeschiedenis van overtredingen en meldingen van incidenten, geschat in afzonderlijke modellen en gecontroleerd voor MARS-categorie en domino-inrichting 
Model $C$ in tabel 3 geeft het volledige model weer waarin (anders dan in figuur 4) zowel bedrijfskenmerken, overtredingsgeschiedenis als het aantal eerder door het bedrijf gemelde incidenten tegelijkertijd zijn meegenomen. De uitkomsten van dit model laten zien dat wanneer rekening wordt gehouden met bedrijfskenmerken en het aantal eerdere overtredingen, het aantal eerdere incidenten niet langer voorspellend is voor het zich voordoen van een incident met gevaar. Het aantal eerdere meldingen van grotere branden blijft echter een belangrijke voorspeller van toekomstige grotere branden, ook wanneer rekening gehouden wordt met bedrijfskenmerken en overtredingsgeschiedenis in de periode 2012-2014.

In het laatste model in tabel 3, Model D, is ook bedrijfsgrootte opgenomen. Aangezien er over slechts een beperkt aantal bedrijven informatie over bedrijfsgrootte aanwezig was in de op dat moment beschikbare data, is de variabele 'grootte' voor de overige bedrijven geïmputeerd. Dit wil zeggen dat de grootte van deze bedrijven middels een statistische procedure (multiple imputation) is geschat op basis van alle wel bekende kenmerken van die bedrijven en de kenmerken van bedrijven waarvan de grootte wel bekend was. Ook wanneer gecontroleerd wordt voor bedrijfsgrootte, blijkt dat alleen het aantal meldingen van eerdere grotere branden voorspellend is voor het risico op een grotere brand na 1 januari 2015.

\section{Discussie}

In dit artikel stond de voorspelbaarheid van loss of containment-incidenten bij Brzo-bedrijven centraal. Op basis van een combinatie van inspectiegegevens uit de GIR-database en de openbaar toegankelijke database van incidenten kon voor 65 Brzo-bedrijven gevestigd in de Veiligheidsregio Rotterdam-Rijnmond worden nagegaan in welke mate eerder door inspecteurs geconstateerde overtredingen van de Seveso-wetgeving voorspellend zijn voor het zich voordoen van een incident bij het desbetreffende bedrijf. Tegen de verwachting in laten de resultaten van de huidige analyses zien dat de bedrijfsgeschiedenis van regelovertreding niet voorspellend is voor het zich voordoen van een incident met gevaar of een grotere brand bij een bedrijf. Dit geldt voor verschillende aspecten van regelovertreding, waaronder het type, de ernst en de diversiteit van regelovertreding. Deze resultaten blijven overeind, ook als rekening gehouden wordt met de bedrijfssector en de grootte van het bedrijf. Eerdere meldingen van grotere branden zijn wel voorspellend voor het zich (opnieuw) voordoen van een grotere brand.

Voor de gevonden resultaten zijn verschillende verklaringen denkbaar. Een verklaring voor de bevindingen is dat het overtreden van veiligheidsregels geen effect heeft op het zich voordoen van incidenten. In dat geval is de huidige Brzoregelgeving mogelijk geen goede reflectie van de relevante leading indicatoren. Alternatieve verklaringen voor het ontbreken van een verband zouden ten eerste gelegen kunnen zijn in een onderliggende variabele die een eventueel verband in de huidige analyses opheft. Zo berusten de beschikbare gegevens over incidenten op zelfrapportage van de betrokken bedrijven. Mogelijk zijn bedrijven die de procesveiligheid hoog in het vaandel hebben staan en zich strikt houden aan de Seveso-regels, sterker geneigd incidenten te melden dan bedrijven waar dit niet 


\begin{tabular}{|c|c|c|c|c|c|c|c|c|}
\hline \multirow[t]{2}{*}{ Incidenten met gevaar } & \multicolumn{2}{|c|}{ Model A } & \multicolumn{2}{|c|}{ Model B } & \multicolumn{2}{|c|}{ Model C } & \multicolumn{2}{|c|}{ Model D } \\
\hline & $\operatorname{Exp}(B)$ & sign. & $\operatorname{Exp}(B)$ & sign. & $\operatorname{Exp}(B)$ & sign. & $\operatorname{Exp}(B)$ & sign. \\
\hline \multicolumn{9}{|l|}{ MARS categorie } \\
\hline bulkchemie & 2,248 & ** & 2,477 & ** & 2,387 & ** & 2,099 & \\
\hline olie, rubber, plastic en fijnchemie & 3,041 & ** & 3,792 & $* * *$ & 2,421 & & 1,603 & \\
\hline handel en distributie & ref. & & ref. & & ref. & & ref. & \\
\hline overig MARS & 1,989 & & 2,611 & & 2,783 & & 1,452 & \\
\hline \multicolumn{9}{|l|}{ Domino } \\
\hline ja & 2,012 & & 1,996 & & 2,137 & & 2,454 & \\
\hline \multicolumn{9}{|l|}{ Bedrijfsgrootte ${ }^{1}$} \\
\hline micro & & & & & & & 2,114 & \\
\hline klein & & & & & & & 0,423 & \\
\hline middelgroot & & & & & & & 1,918 & \\
\hline groot & & & & & & & ref. & \\
\hline \multicolumn{9}{|l|}{ Overtredingsgeschiedenis 2012-2014 } \\
\hline aantal overtredingen & & & 2,085 & & 1,964 & & 1,489 & \\
\hline aantal verschillende overtredingen & & & & & 0,994 & & 1,030 & \\
\hline \multicolumn{9}{|l|}{ Geschiedenis ongewone voorvallen 2012-2014 } \\
\hline aantal incidenten zonder gevaar ${ }^{1}$ & & & & & 1,014 & & 1,018 & \\
\hline aantal incidenten met gevaar ${ }^{2}$ & & & & & 1,254 & & 1,308 & \\
\hline \multirow[t]{2}{*}{ Grotere branden } & \multicolumn{2}{|c|}{ Model A } & \multicolumn{2}{|c|}{ Model B } & \multicolumn{2}{|c|}{ Model C } & \multicolumn{2}{|c|}{ Model D } \\
\hline & $\operatorname{Exp}(B)$ & sign. & $\operatorname{Exp}(B)$ & sign. & $\operatorname{Exp}(B)$ & sign. & $\operatorname{Exp}(B)$ & sign. \\
\hline \multicolumn{9}{|l|}{ MARS categorie } \\
\hline bulkchemie & 2,961 & ** & 3,080 & ** & 3,444 & $* *$ & 4,574 & $* *$ \\
\hline olie, rubber, plastic en fijnchemie & 3,764 & $* *$ & 3,821 & $* *$ & 2,088 & & 2,165 & \\
\hline handel en distributie & ref. & & ref. & & ref. & & ref. & \\
\hline overig MARS & 5,782 & $* * *$ & 4,517 & & 5,682 & ** & 4,573 & * \\
\hline \multicolumn{9}{|l|}{ Domino } \\
\hline ja & 1,750 & & 1,918 & & 2,234 & & 2,271 & \\
\hline \multicolumn{9}{|l|}{ Bedrijfsgrootte ${ }^{1}$} \\
\hline micro & & & & & & & 1,465 & \\
\hline klein & & & & & & & 0,285 & \\
\hline middelgroot & & & & & & & 0,737 & \\
\hline groot & & & & & & & ref. & \\
\hline \multicolumn{9}{|l|}{ Overtredingsgeschiedenis 2012-2014 } \\
\hline aantal overtredingen & & & 1,399 & & 0,850 & & 0,608 & \\
\hline aantal verschillende overtredingen & & & & & 1,052 & & 1,147 & \\
\hline \multicolumn{9}{|l|}{ Geschiedenis ongewone voorvallen 2012-2014 } \\
\hline aantal incidenten met of zonder gevaar ${ }^{2}$ & & & & & 1,025 & & 1,017 & \\
\hline aantal grotere branden ${ }^{4}$ & & & & & 2,106 & $* * *$ & 2,213 & $* * *$ \\
\hline \multicolumn{9}{|l|}{${ }^{*} p<0.1 ;{ }^{* *} p<0.05 ;{ }^{* * *} p<0.01$} \\
\hline \multicolumn{9}{|l|}{ 'Categorie $2,7,8,9$ en 10 (Tabel 1 ) } \\
\hline${ }^{2}$ Categorie $1,3,4,5$ en 6 (Tabel 1 ) & & & & & & & & \\
\hline${ }^{3}$ Categorie $2 \mathrm{t} / \mathrm{m} 10$ (Tabel 1$)$ & & & & & & & & \\
\hline${ }^{4}$ Categorie 1 (Tabel 1 ) & & & & & & & & \\
\hline
\end{tabular}

\section{Tabel 3 Resultaten Cox-regressies voor incidenten met gevaar en grotere branden} (categorie 1)

het geval is. In dat geval ontstaat de paradoxale situatie waarin veilige bedrijven schijnbaar vaker te maken hebben met incidenten dan onveilige bedrijven (Van der Schaaf \& Kanse, 2004). Om vertekening in de afhankelijke variabele door zelfrapportage tegen te gaan, zijn de voorspellingsmodellen echter herhaald voor alleen grotere branden waarbij brandweerassistentie gevraagd is. Ook in deze modellen blijkt de bedrijfsgeschiedenis van regelovertreding niet voorspellend voor latere incidenten, hetgeen de algemene conclusie van dit artikel, dat eerdere regelovertreding niet voorspellend is voor toekomstige procesveiligheidsincidenten, onderschrijft. Bedrijfsgrootte is een andere voor de hand liggende variabele die een eventueel verband tussen regelovertreding en incidenten zou kunnen verhullen, bijvoorbeeld doordat grote bedrijven meer expertise in huis hebben om de regels na te kunnen leven, maar vanwege een groter aantal installaties meer inci- 
denten meemaken. In de analyses is echter voor bedrijfsgrootte gecontroleerd, waardoor ook deze verklaring aan waarschijnlijkheid verliest.

Een andere oorzaak voor het ontbreken van voorspellende waarde van regelovertreding voor incidenten kan zijn gelegen in een mogelijke discrepantie tussen de werkelijke regelovertreding en de geregistreerde regelovertreding. Een dergelijk dark number kan worden veroorzaakt doordat niet alle overtredingen worden opgemerkt, bijvoorbeeld omdat tijdens een inspectie doorgaans niet alle verschillende thema's worden geïnspecteerd. Hier staat tegenover dat uit eerdere analyses van de GIR-data is gebleken dat bedrijven die veel overtredingen begaan ook veel verschillende regels overtreden (Kluin, Wiering, Peeters, Blokland \& Huisman, in druk), hetgeen deze verklaring minder aannemelijk maakt. Een andere mogelijke oorzaak voor een dark number kan zijn gelegen in de hoge mate van discretionaire bevoegdheid die inspecteurs is toebedeeld in de afdoening van geconstateerde regelovertreding, wat resulteert in verschillende handhavingsstijlen (Kluin, 2014). Nader onderzoek naar de verschillende stappen tussen constatering van overtredingen en registratie in de GIR en de mogelijk hieruit voortvloeiende vertekening is daarom gewenst.

Tot slot zijn de huidige analyses beperkt tot 65 Brzo-bedrijven in de regio Rotterdam-Rijnmond. De kleine steekproef kan ertoe hebben geleid dat minder sterke voorspellers worden gemist. Bovendien kunnen de huidige resultaten vanwege de geografische afbakening van de huidige steekproef niet zonder meer worden gegeneraliseerd naar alle (Nederlandse) Brzo-bedrijven. Vervolgonderzoek waarbij ook incidenten gerapporteerd door Brzo-bedrijven uit de andere veiligheidsregio's worden meegenomen, is daarom een logische volgende stap. Ook zou vervolgonderzoek zich moeten richten op de mogelijk voorspellende waarde van indirecte leading veiligheidsindicatoren, gebaseerd op vigerende veiligheidsmodellen. Hoewel eerder buitenlands onderzoek verbanden heeft gevonden tussen bijvoorbeeld economische strain en regelovertreding, is het verband tussen strain en incidenten - al dan niet gemedieerd door de mate van regelovertreding - nog niet eerder op basis van longitudinale data onderzocht. Het koppelen van gegevens uit verschillende databronnen zoals de GIR, Kamer van Koophandel en jaarverslagen brengt een dergelijk onderzoek echter wel steeds meer innen bereik.

Een implicatie voor de toezichtspraktijk die ondanks de hiervoor beschreven kanttekeningen voortvloeit uit de huidige situatie, heeft betrekking op de inzet van toezichtcapaciteit. Inspectiediensten zijn wettelijk verplicht elk Brzo-bedrijf minimaal één keer per jaar te inspecteren, maar kunnen zelf bepalen hoe zij hun overige capaciteit besteden. Geprobeerd wordt deze capaciteit zo efficiënt mogelijk te benutten, door deze in te zetten voor toezicht op frequent overtredende bedrijven (Inspectie SZW, 2018). Uit de huidige resultaten blijkt echter dat geregistreerde regelovertreding geen voorspellende waarde heeft voor incidenten. Nader onderzoek is nodig om duidelijkheid te kunnen verschaffen rondom het gebruik van geregistreerde overtredingen als basis voor de inzet van inspectiecapaciteit. Eerder gemelde incidenten blijken wel voorspellend voor latere incidenten en zijn in dit kader mogelijk een nuttig alternatief. Een kanttekening hierbij is wel dat dit zou kunnen bijdragen aan terughoudendheid bij het melden van incidenten door bedrijven. 
De huidige studie vindt geen verband tussen eerdere regelovertreding en latere incidenten bij chemische bedrijven. Om het ontbreken van dit verband te kunnen duiden is nader onderzoek nodig. Daarbij kan enerzijds gedacht worden aan het gebruik van een grotere steekproef van bedrijven en informatie over belangrijke push- en pullfactoren die kunnen maken dat bedrijven opschuiven richting de grens van veilig werken en anderzijds aan nader kwalitatief onderzoek onder inspecteurs en bedrijven om beter inzicht te verkrijgen in de verklaring van (het schijnbaar ontbreken van) de relatie tussen regelovertreding en ongevalsrisico. Nader onderzoek onder een grotere steekproef en met informatie over belangrijke push- en pullfactoren die kunnen maken dat bedrijven opschuiven richting de grens van veilig werken, is hiervoor essentieel. Tot slot is het belangrijk zich te blijven realiseren dat toezicht en handhaving meer behelst dan het rapporteren en sanctioneren van overtredingen van de veiligheidsregels; ook de regelmatige aanwezigheid van inspecteurs en hun adviserende rol zijn hiervan belangrijke aspecten die kunnen bijdragen aan het verhogen van de veiligheidssituatie in deze risicovolle tak van de Nederlandse industrie.

\section{Literatuur}

Agnew, R. (1992) Foundation for a general strain theory of crime and delinquency. Criminology, 30(1), 47-88.

Agnew, R., N.L. Piquero \& F.T. Cullen (2009) General strain theory and white-collar crime. In: S.S. Simpson (ed.), The criminology of white-collar crime. New York: Springer, 35-60.

Aksorn, T. \& B.H. Hadikusumo (2008) Measuring effectiveness of safety programmes in the Thai construction industry. Construction Management and Economics, 26(4), 409-421.

Algemeen Dagblad (2017) Ook RIVM vindt Genx in drinkwater. Geraadpleegd op www.ad.nl/binnenland/ook-rivm-vindt-genx-in-drinkwater aa0e12ed.

Arocena, P. \& I. Nunez (2009) The effect of occupational safety legislation in preventing accidents at work. Traditional versus advanced manufacturing industry. Environment and Planning C: Government and Policy, 27(1), 159-174.

Boden, L.I. (1985) Government regulation of occupational safety. Underground coal mine accidents 1973-75. American Journal of Public Health, 75(5), 497-501.

Braithwaite, J. (1992) Poverty, power and white-collar crime. In: K. Schlegel \& D. Weisburd (ed.), White-collar crime reconsidered. Boston: North-eastern University Press, 78-107.

Brown, R.L. \& H. Holmes (1986) The use of a factor - analytic procedure for assessing the validity of an employee safety climate model. Accident Analysis and Prevention, 18(6), 445-470.

Brzoplus (2014) Handreiking voor het toepassen van de landelijke handhavingsstrategie Brzo 1999. Rijswijk: Bureau Brzoplus.

Bureau Bartels (2012) Onderzoek vergelijkbaarheid inspectieruimten. Amersfoort: Bureau Bartels.

Cambon, J., F. Guarnieri \& J. Groeneweg (2006) Towards a new tool for measuring Safety Management Systems performance. In: E. Hollnagel \& E. Rigaud (ed.) Proceedings of the second resilience engineering symposium. Juan-les-Pins: Mines Paris Les Presses, 53-62.

Clinard, M.B. \& P.C. Yeager (1980) Corporate Crime. New York: Free Press. 
Curington, W.P. (1986) Safety regulation and workplace injuries. Southern Economic Journal, 53(1), 51-72.

DCMR (2017) Gedragslijn melden van ongewone voorvallen in het Rijnmondgebied. Geraadpleegd op www.dcmr.nl/onderwerpen/bedrijfsmelding.

Eindhovens Dagblad (2017) Twee waterschappen in Brabant beginnen onderzoek naar hoge hoeveelheden Genx. Geraadpleegd op www.ed.nl/eindhoven/tweewaterschappen-inbrabant-beginnen-onderzoek-naar-hoge-hoeveelheden-genx a44278d7.

Filer, R.K. \& D.L. Golbe (2003) Debt, operating margin, and investment in workplace safety. The Journal of Industrial Economics, 51(3), 359-381.

Fishback, P.V. (1986) Workplace safety during the progressive era. Fatal accidents in bituminous coal mining 1912-1923. Explorations in Economic History, 23(3), 269-298.

Goldenhar, L.M., L.J. Williams \& N.G. Swanson (2003) Modelling relationships between job stressors and injury and near-miss outcomes for construction labourers. Work \& Stress, 17(3), 218-240.

Grabowski, M., P. Ayyalasomayajula, J. Merrick, J.R. Harrald \& K. Roberts (2007) Leading indicators of safety in virtual organizations. Safety Science, 45(10), 1013-1043.

Gray, W.B. \& J.M. Mendeloff (2005) The declining effects of OSHA inspections on manufacturing injuries 1979-1998. ILR Review, 58(4), 571-587.

Gray, W.B. \& J.T. Scholz (1993) Does regulatory enforcement work? A panel analysis of OSHA enforcement. Law and Society Review, 27(1) 177-213.

Hale, A. (2009) Why safety performance indicators?. Safety Science, 4(47), 479-480.

Hayes, B.E., J. Perander, T. Smecko \& J. Trask (1998) Measuring perceptions of workplace safety. Development and validation of the work safety scale. Journal of Safety Research, 29(3), 145-161.

Heinrich, H.W. (1959) Industrial Accident Prevention. A Scientific Approach. New York: McGraw-Hill.

Hollnagel, E. (2004) Barriers and accidents prevention. Aldershot: Ashgate.

Hollnagel, E. (2008) Risk + barriers = safety?. Safety Science, 46(2), 221-229.

Hopkins, A. (2009) Thinking about process safety indicators. Safety Science, 47(4), 460-465.

Inspectie SZW (2018) Jaarplan 2018. Utrecht: Inspectie SZW.

Jenkins, A. \& J. Braithwaite (1993) Profits, pressure and corporate lawbreaking. Crime, Law and Social Change, 20(3), 221-232.

Kenniscentrum InfoMil (2018) Handreiking bij titel 17.2 Wet milieubeheer: maatregelen bij milieuschade of een onmiddellijke dreiging daarvan. Geraadpleegd op www.infomil.nl/ onderwerpen/integrale/wet-milieubeheer/(hst-17-2)/handreiking.

Kluin, M.H.A. (2014) Optic compliance. Enforcement and compliance in the Dutch chemical industry. Delft: TU Delft.

Kluin, M.H.A., A.A.J. Blokland, W. Huisman, M.P. Peeters, E. Wiering \& S.J. Jaspers (2018) Patronen in regelovertreding in de chemische industrie. Tijdschrift voor Criminologie, 59(4), 421-457.

Kluin, M.H.A., E. Wiering, M.P. Peeters, A.A.J. Blokland \& W. Huisman (in druk), Regeloverteding in de chemische industrie. Een levensloopbenadering. Utrecht: Centrum voor Criminaliteitspreventie en Veiligheid.

Langton, L. \& N.L. Piquero (2007) Can general strain theory explain white-collar crime? A preliminary investigation of the relationship between strain and select white-collar offenses. Journal of Criminal Justice, 35(1), 1-15.

LAT Brzo (2008) Werkwijzer Brzo 1999 I Versie 2. Den Haag: Deltahage.

Lewis-Beck, M.S. \& J.R. Alford (1980) Can government regulate safety? The coal mine example. American Political Science Review, 74(3), 745-756. 
Lundberg, J., C. Rollenhagen \& E. Hollnagel (2009) What-You-Look-For-Is-What-YouFind. The consequences of underlying accident models in eight accident investigation manuals. Safety science, 47(10), 1297-1311.

Merton, R.K. (1938) Social structure and anomie. American Sociological Review, 3(5), 672-682.

NRC (2014) Explosie en brand in Moerdijk. Geraadpleegd op www.nrc.nl/nieuws/ 2014/06/03/explosie-en-brand-in-moerdijk-a1424558.

NRC (2018) Verhoogde concentraties Pfoa en Genx in omgeving Chemours. Geraadpleegd op www.nrc.nl/nieuws/2018/07/13/verhoogde-concentraties-pfoa-en-genx-inomgeving-chemours-a1609894.

Nu.nl (2018) RIVM adviseert omwonenden Chemours Dordrecht niet te vaak uit hun tuin te eten. Geraadpleegd op www.nu.nl/binnenland/5165504/rivm-adviseertomwonenden-chemours-dordrecht-niet-vaak-tuin-eten.html.

Onderzoeksraad voor Veiligheid (2012) Brand bij Chemie-Pack te Moerdijk. Den Haag: Onderzoeksraad voor Veiligheid.

Onderzoeksraad voor Veiligheid (2013) Veiligheid Odfjell Terminals Rotterdam, periode 2000-2012. Den Haag: Onderzoeksraad voor Veiligheid.

Passas, N. (1990) Anomie and corporate deviance. Contemporary Crises, 14(2), 157-178.

Perrow, C. (1984) Normal Accidents. Living with high risk technologies. New York: Princeton University Press.

Qureshi, Z.H. (2007) A review of accident modeling approaches for complex socio-technical systems. Edinburgh: Defence Science and Technology Organisation.

Rasmussen, J. (1997) Risk management in a dynamic society: a modelling problem. Safety Science, 27(2-3), 183-213.

Reason, J. (1990) Human error. New York: Cambridge University Press.

Salvi, O., A. Jovanovic, C. Bolvin, C. Dupuis, C. Vaquero, D. Balos \& A.M. Villamizar (2008) F-Seveso. Study of the effectiveness of the Seveso II directive. EU-VRi.

Schaaf, T. van der \& L. Kanse (2004) Biases in incident reporting databases. An empirical study in the chemical process industry. Safety Science, 42(1), 57-67.

Simpson, S.S. \& C.S. Koper (1997) The changing of the guard. Top management characteristics, organizational strain, and antitrust offending. Journal of Quantitative Criminology, 13(4), 373-404.

Smith, R.S. (1979) The impact of OSHA inspections on manufacturing injury rates. Journal of Human Resources, 14(2), 145-170.

Staw, B.M. \& E. Szwajkowski (1975) The scarcity-munificence component of organizational environments and the commission of illegal acts. Administrative Science Quarterly, 20(3), 345-354.

Swuste, P.H.J.J., J. Theunissen, P. Schmitz, G.L.L. Reniers \& P.J. Blokland (2016) Process safety indicators. A review of literature. Journal of Loss Prevention in the Process Industries, 40, 162-173.

Turner, B.A. \& N.F. Pidgeon (1997) Man-made disasters. Oxford: Blackwell Publishing.

Vinodkumar, M.N. \& M. Bhasi (2009) Safety climate factors and its relationship with accidents and personal attributes in the chemical industry. Safety Science, 47(5), 659-667.

Volkskrant (2011a) Hoogste alarmfase door megabrand Moerdijk. Geraadpleegd op www.volkskrant.nl/mensen/hoogste-alarmfase-door-megabrand-moerdijk b0ea16b1.

Volkskrant (2011b) Rotterdam bedrijf houdt groot gaslek stil. Geraadpleegd op www.volkskrant.nl/nieuws-achtergrond/rotterdams-bedrijf-houdt-groot-gaslekstil bccc1ad98. 
Volkskrant (2017) Nog steeds veel gif in bloed van omwonenden Dupont in Dordrecht. Geraadpleegd op www.volkskrant.nl/economie/nog-steeds-veel-gif-in-bloed-vanomwonenden-dupont-in-dordrecht b20dd568.

Waring, E.J., D.L. Weisburd \& E.F. Chayet (1995) White-collar crime and anomie. In: F. Adler \& W.S. Laufer (ed.), The legacy of anomie theory. New Brunswick: Transaction Publishers, 207-225.

Zohar, D. (2000) A group-level model of safety climate. Testing the effect of group climate on microaccidents in manufacturing jobs. Journal of Applied Psychology, 85(4), 587-596. 